\title{
Understanding Islamic Ethics and Its Significance on the Character Building
}

\author{
Adibah Binti Abdul Rahim
}

\begin{abstract}
The most critical challenge facing Muslim today is the lack of the spiritual ethical dimension of life, and one of the most powerful means to overcome this problem is the adherence to the code of ethics. This paper attempts at clarifying the concept of Islamic ethics as a basic pillar for a healthy society. It explains about the need of ethics for the development of individual and society, and its significance on the character building. The author tries to present ethics as the counter part of other sciences, such as, law, politics, science, economics, and others for such sciences become soulless or insignificant if detached from ethics. The paper concludes that Muslim character should develop along with Islamic ethics and its application into daily affairs of Muslims' lives should be given its due attention.
\end{abstract}

Index Terms - Ethics and morality, Islamic ethics, character building

\section{INTRODUCTION: DEFINITIONS AND SOURCES OF ISLAMIC ETHICS}

Islamic ethics is being defined as akhlaq (plural of khuluq) which means character, nature, and disposition. The word akhlaq has a very close relationship with the word khaliq (the Creator) and makhluq (the creature). Therefore, akhlaq assumes a good relationship between khaliq(the Creator) and makhluq (the creature), and between makhluq (the creature) and makhluq (the creature) themselves. The term khuluq appears in the Qur'anic verse "And You (Muhammad) are on an exalted standard of character" ${ }^{1}$. Khuluq (akhlaq) or character has been referred as the state of the soul that determines human actions. It is neither the soul nor the action. Such character could be acquired through training and practice [1]. In addition, to differentiate between the words character and action, character is the internal and hidden state of the soul, while action is its outward manifestation. Character or akhlaq is the inward cause while action is its outward consequences. A good character hence begets good action whereas a bad character yields bad actions ${ }^{2}$. Al-Farabi (d. 950) was to be known as the earliest great Muslim philosopher who acknowledged the interrelation of akhlaq or the state of the soul with human action ${ }^{3}$. Indeed, he defined

Manuscript received June 1, 2013; revised August 10, 2013.

Adibah Binti Abdul Rahim is with the International Islamic University Malaysia (IIUM), Malaysia (e-mail: adibahar@iium.edu.my).

${ }^{1}$ Qur'an: 68: 4. See also Qur'an 26: 137.

${ }^{2}$ Mohd Nasir Omar, Christian and Muslim Ethics, Kuala Lumpur: Dewan Bahasa dan Pustaka, 2003, pp. 4.

${ }^{3}$ In his work Fusul, al-Farabi emphasized that "the states of soul by which a man does deeds and fair actions are virtues, and those by which he does wicked deeds and ugly actions, are the vices'. Refer to Mohd Nasir Omar, Christian and Muslim Ethics, pp. 4.
Islamic ethics or akhlaq as 'a science that studies the state of human soul'. Besides al-Farabi, Ibn Miskawayh (d. 1030) in his work Tahzib al-Akhlaq defined akhlaq as 'a state of the soul which causes it to perform its actions without thought or deliberation'. The definition of akhlaq as the science of the human soul was further elaborated by successive writers and philosophers on Islamic ethics, such as, al-Ghazali (d.1111), Fakhruddin al-Razi (d. 1209), al-Tusi (d. 1274), al-Dawani (d. 1502), and others ${ }^{4}$. Overall, they defined ethics or ilm al-akhlaq as the science of the human soul which defines the characteristics and qualities of the soul as well as the methods of how to control and moderate them ${ }^{5}$.

Al-Ghazali stated that man consists of two forms, khalq and khuluq or akhlaq. Khalq refers to the physical form of mankind while khuluq or akhlaq refers to the spiritual form of mankind. Thus, akhlaq from al-Ghazali's point of view is rooted in the soul and manifested through man's actions. Good soul will produce right action and vice versa. Al-Ghazali defined Islamic ethics or ilm al-akhlaq as the way to acquire the well being of the soul and to guard it against the vices. It is also a study of certain religious beliefs and of rightness or wrongness of actions for the purpose of practice, and not for the sake of mere knowledge. For him, the study of akhlaq includes the study of right actions towards God, family members, and society. Thus, the scope of akhlaq, according to al-Ghazali, is very wide [2]. Meanwhile, according to Ibn Taymiyyah, Islamic ethics or ilm al-akhlaq is a science that seeks to know which actions should be done and which should be avoided. It is a practical science meant to be applied [3]. Accordingly, Islamic ethics or 'ilm al-akhlaq is a science which deals with the ways to maintain virtues at their optimum level, i.e, to avoid wrongdoing and to do what is right and desirable [4]. The scope of Islamic ethics is numerous, far reaching and comprehensive because Islamic ethics deals with the relationship between man and God, man and his fellow men, men and other creatures of the universe, and man with his innermost self.

Meanwhile, the two primary sources of Islamic ethics are the Qur'an and Sunnah of the Prophet Muhammad (p.b.u.h). Al-Qur'an is the most significant source given by God for the human being to refer to pertaining to human conduct besides the Sunnah of the Prophet Muhammad (p.b.u.h) as the role model to be imitated. Both Qur'an and the Sunnah of the Prophet Muhammad (p.b.u.h) are called the scriptural morality. There are some elements in the Qur'an which can be considered as fundamental problems of ethics, such as, i) the nature of right and wrong, ii) divine justice and power, and iii) freedom and responsibility [5]. With regards to the

\footnotetext{
${ }^{4}$ ibid

ibid, pp. 6 .
} 
first problem, the Qur'an uses a whole cluster of terms to denote the concept of moral or religious goodness, such as, al-khayr (goodness), al-birr (righteousness), al-qisr and al-iqsat (equity), al-adl (justice), al-haqq (truth and right), al-ma'ruf(known and approved), and al-taqwa (piety). Pious actions are normally referred to as salihat, whereas impious or sinful actions are termed sayyi' $a t^{6}$. The term like $m$ 'aruf, $k h a y r$, and al-birr which occur in many verses ${ }^{7}$ express the moral and religious spirit of the Qur'an. The second fundamental ethical issue in the Qur'an is regarding the divine justice. There are several verses in the Qur'an that are related to the divine justice, such as, verses that enjoin justice $^{8}$, disapprove of the unjust ${ }^{9}$, and love the equitable and pious in which to show that God is not an unjust dealer with His servants ${ }^{10}$. Meanwhile, the third ethical problem in the Qur'an is regarding the human responsibility ${ }^{11}$. The term used is yus'alu in which it is used in passive voice in a morally neutral sense that would be referred as the meaning of 'liable to question' such as responsible or answerable for doing or believing that which is clearly reprehensible. In some of the verses, the unbelievers or polytheists are stated to be answerable to God for their misdeeds or disbelief on the Day of Judgment while in others this answerability is expressed much broader terms that illustrate the general imperative of moral responsibility.

The other source of Islamic ethics is Islamic theology. Theologians did not enter into normative questions of Islamic ethics. They discussed the source of ethical knowledge, the basis of moral obligation and the meaning of ethical terms. Besides these epistemological and meta-ethical questions, they also discussed the questions of human freedom and responsibility, and divine justice. The theologians have taken various positions on these ethical questions. The determinists for instance, upheld the absoluteness of divine power, denied the reality of human freedom and responsibility, and did not try to justify divine justice [6]. Meanwhile, another group of theologians, the Mu'tazilite, asserted man has power and freedom to choose and act through reason. They stated that acts like prayers, fasting, and zakah are determined good through revelation. However, there are other things that can be determined good through reason. For the Mu'tazilites, moral obligation is rational. The pronouncements of reason, they said, are binding not only on man but also on God. According to Mu'tazilites, God must reward the righteous and punish the wicked acts. This is what they called divine justice. Meanwhile, Ash'arite theologians took a middle position between absolute determinism and the self-sufficiency of human will ${ }^{12}$. The Ash'arites was of the opinion that revelation is the only way to know the good and the right. They did not accord any role to reason except in knowing what is pleasant, useful or harmful. Nothing is obligatory, they said, unless revelation commands it. Reason

\footnotetext{
${ }^{6}$ Majid Fakhry, Ethical Theories in Islam, Netherlands: E. J Brill, 1991, p. 11.

${ }^{7}$ Qur'an 2: 263, 3: 104, 114-115, 22:77.

${ }^{8}$ Qur'an 7:29, 16: 90

${ }^{9}$ Qur'an 3: 57, 140, 42: 40.

${ }^{10}$ Qur'an 3: 183, 8: 51, 22: 10, 41: 46.

${ }^{11}$ Majid Fakhry, Ethical Theories in Islam, pp. 18.

${ }^{12}$ Abdul Haq Ansari, "Islamic Ethics: Concept and Prospect", in The American Journal of Islamic Social Sciences, vol. 6, no. 1, 1989, pp.86.
}

is not the basis of obligation ${ }^{13}$. The Maturidis and the Salafi (Ibn Taymiyyah), however, agreed partly with the Mu'tazilites. They claimed that reason does reveal things that are good, bad, right, or wrong in the ethical sense; but there is a limit to it in which there are things that are known to be good or bad only through revelation. Ibn Taymiyyah has also pointed out that if something is right or wrong for human beings, it is not necessarily so for God. The proposition that rational judgments are true for every rational being, including God, is not true. Some rules, such as, speaking the truth and keeping promises, are true for men as well as God. But some things, such as, causing death, pain, suffering to creatures, that are wrong for man are not wrong for $\mathrm{God}^{14}$ since He has absolute power over anything.

Other than Islamic theology, Islamic philosophy also becomes one of the important sources of Islamic ethics. The Muslim philosophers, such as, Abu Nasr Farabi (d. 950), Abu Ali Miskawayh (d. 1030), Nar al- Din Tusi (d. 1273), and Jalal al-Din Dawwani (d. 1502) concerned with the problem of goodness. Similar to Greek ethics, these philosophers dealt with an investigation into the ultimate good or good in itself, which is happiness or saadah. Muslim philosophers also shared the same view with Greek ethics in analyzing moral in terms of virtues of the faculties of the soul; the rational, the irascive, and the appetitive. The virtue of the rational was wisdom, the virtue of the irascive was courage, the virtue of the appetitive was temperance, and the virtue of the entire soul was justice. Muslim philosophers followed this division and tried to categorize all the virtues of life under these four heads $^{15}$. The Greek philosophers, however, made a distinction between knowledge and moral virtue. According to them, pure knowledge was regarded as the ultimate perfection of man and the highest good while moral virtue or righteous conduct was regarded as the proximate perfection and a lower good. Meanwhile, Muslim philosophers like al-Farabi, al-Ghazali, and others considered that nothing was good in itself except knowledge, and made every other good subservient to it $^{16}$.

On the other hand, Islamic jurisprudence also could be the important source for Islamic ethics. There are many works of Islamic jurisprudence which discussed some normative questions and touched on the knowledge of the shariah rules and the basis of their obligation. Besides, Muslim jurists like al-Ghazali (d.111) in al-Mustafa, Ibn Abd al-Salam (d. 1262) in Qawaid al-Ahkam fi Masalih al-Anam, and Abu Ishaq al-Shatibi (d. 1388) in al-Muwafaqat have discussed about the objective of shariah. Al-Shatibi, for instance, stated that

"The rules of the shariah have been designed to produce goods (masalih) and remove evil (mafasid) and these are certainly their ends and objects. And the masalih are those which promote the preservation and fulfillment of human life, and the realization of all that the human nature, animal and rational demands, till one is happy in every aspect" [7].

The statement clearly shows that the objective of the shariah is to secure the balanced well-being of man as well as

\footnotetext{
${ }^{13}$ ibid

14 ibid

${ }^{15}$ ibid

${ }^{16} \mathrm{ibid}$
} 
to fulfill man's comprehensive needs as a human being. Al-Shatibi also discussed the priorities of the shariah. Apart from the discussion of the objective and priorities of shariah, Muslim jurists also discussed about the levels of obligation, and the factors that may upgrade or downgrade the obligation of individual acts. There was also a discussion on motive and its affect on judgments regarding actions and the recompense thereupon, here or hereafter.

The last source of Islamic ethics is Islamic mysticism. There are three categories of the Islamic mysticism writings. The first category of writings extols the ecstatic experience of union with God as the highest goal of human endeavor, and urges that the whole life be geared to that end. This is the view of Shaykh Abdullah al-Ansari al-Harawi (d. 1049). The second category of writings asserts that it is not ecstatic union but rather, the realization in knowledge that reality is one is the highest goal. There are different interpretations of this truth among the sufis. The third category of writings says that the ecstatic experience of union with God is only a stage in the spiritual pursuit (suluk) of the mystic. It has to be transcended, and the unbridgeable difference between God and man has been realized. That realization is the final end of the sufi pursuit. The exponent of this view is Shaykh Ahmad Sirhindi (d. 1627). He claims that without treading the sufi path and going through these experiences, one cannot attain the true concept of servant hood (ubudiyyah), that is, one wills nothing but the will of $\operatorname{God}^{17}$. In order to realize their goal, sufis prescribe a discipline of life, a method of purification of the soul, and the way of worship, devotion and contemplation, which are partly based on the teachings of the Prophet (p.b.u.h) and partly developed in the light of experience. These two components of the sufi way (Tariqah) vary in their relative strength from group to group and individual to individual. Accordingly, exercises in asceticism, renunciation, devotion, and contemplation vary in rigor ${ }^{18}$.

\section{THE RELATIONSHIP BETWEEN ISLAMIC ETHICS AND SHARIAH}

Shariah or Islamic law is the command of God revealed to the Prophet (p.b.u.h), and it is a law that controls the state and society. It means that state and society have to conform to the dictates of shariah. Shariah is different from the human law due to its divine origin which is based on divine revelations. It is very much different from the views of Plato who said that law belongs to the class of convention; if all parties or people agreed upon one issue then it could be the law, and if they did not agree then it could not be the law. Therefore, Islamic law or shariah differs from human law since human law is the product of reason and outcome of customary rules. It can never produce a perfect uniformity of conduct. The good for one group of people is not necessarily so for another group, thus, the practice of moral conduct would be different from one another. Meanwhile, Islamic law or shariah is able to produce perfect standard rules of conduct within all aspects of man's life. It lies down the specific norms of good and bad, virtue and vice.

\footnotetext{
${ }^{17}$ Abdul Haq Ansari, Islamic Ethics: Concept and Prospect, pp. 90.

${ }^{18}$ Ibid.
}

The objective of Islamic law or shariah is seen to be similar with Islamic ethics, that is, to construct human life on the basis of virtues (ma'rufat), and to cleanse it from vices (munkarat). Virtues or ma'rufat, in general, are in harmony with human nature and its requirements, and vices or munkarat are just opposite to virtues. Through shariah, we can get clear view of what are the virtues and the vices, and these are to the norms to which the individual and societal behavior should conform. Islamic law or shariah covers all aspects of man's life from religious rituals up to social, economic, judicial system and so on. As a matter of fact, shariah has much wider scope and purpose as compared to a Western legal system. Like Islamic ethics, shariah aims at regulating the relationship of man with God, and man with man. Therefore, both shariah and Islamic ethics cannot be separated from each other.

In shariah, there are certain limits prescribed by Allah (huddullah) which are imposed on man in order to prevent him from following his own wishes and desires. Allah has clearly mentioned about lawful (halal) and unlawful (haram), virtues and vices. These are limits $(h u d u d)$ which every Muslim must respect and obey, and if he transgressed any of these limits, he is doing wrong or committing a crime. These limits $(h u d u d)$ are to be sanctions of Islamic law or shariah, and that is why it is called as hudud law. Apart from giving man a sense of responsibility to Allah as well as to entire mankind, these limits (hudud) will safeguard the rights of man in all aspects of life.

Therefore, Islamic law or shariah will ensure and safeguard the well being of people (masalih al-ibad). For example, to safeguard the lineage of people, Islamic law provides clearly the punishment for adultery (zina). Adultery or zina means a sexual intercourse between man and a woman not married to each other. Islam considers it not only as a great sin but also as an act which opens the gate to many other shameful acts. The Qur'an mentions,

"Do not come nearer to adultery or zina for it is shameful deed and an evil, opening the road to other evils" $"$.

It is no doubt that adultery is a great $\sin$, and if allowed it to happen, it may disrupt the social fabric of the ummah. For this reason, severe punishment is reserved for adultery. If it is punished softly or not punished at all, it might give bad impact on man's life. It will destroy the basis of family structure, spread numerous diseases both physical as well as spiritual, and lead to broken family. Therefore, Islamic law punishes adultery heavily in order to penalize offenders, and at the same time other people in the same community are warned not to commit similar crimes. Islamic criminal law of adultery is mostly concern to safeguard man's descendent, honor, and lineage as well as to preserve the ethical values.

Another example of Islamic law to safeguard the well being of people is the punishment for theft (al-hirabah or al-sariqah). Islam emphasizes the individual's safety with regard to his life, property, and honor, thus, any threat to these three entities is severely punished by Islamic law. A person who kills or robs another is severely punished because this is the only way to guarantee safety or security for every individual. Concerning theft, Islamic law legislates cutting

\footnotetext{
${ }^{19}$ Qur'an 17: 32
} 
off the thief's hand as a maximum punishment and it must be done under certain conditions. When a person knows that he will lose hand for stealing, this makes stealing a rare possibility. The implication of this punishment would remind man to use each organ of the body honorably and legally. The function of hand is not for stealing. If the hand is used to threaten other people, it is a dangerous hand, thus, deserved to be punished. The punishment of cutting hand off is to give the thief and other people reminder not to deal with it again. If the punishment is imprisonment, the thief might steal again after being released from the prison. As such, all the penal code of Islamic laws will reflect to protect or safeguard the entire humanity and all bring the ethical values behind their punishment.

There are three kinds of punishments in Islamic law;. First, hudud; it is the punishment for the limits which have been closely defined by the Qur'an and the Sunnah. Several offences which have been categorized under hudud are adultery or fornication (zina), false accusation (qazaf), apostasy (riddah), drinking wine (al-khamar), theft (al-hirabah). Second, qisas; it stands for the return of life in case of murder. The punishment for the murderer is killing him back. Third, ta'zir; it is the punishment which is to be decided by the court based on the justification of the qadhi. It depends on the various factors affect the criminal acts. These categories of punishments reflect Islamic law as the law of equality which is consistent with the basic ethical values. A large part of the Qur'an consists of full statements on the necessity of all the ethical values like goodness, kindness, forgiveness, and so on. The terms are like 'adl, qist, ihsan, taqwa, and so on. These are the general directives which helped to motivate people to pursue goodness.

\section{THE SIGNIFICANCE OF ISLAMIC ETHICS}

Islam gives very much emphasis on the importance of ethics and its significance for the development of individual and society. Good individual will produce a good society at large. There are many Qur'anic verses and hadiths which indicate the importance of ethics. The Qur'an mentions,

"Let there arise out a group of people inviting to all that

is good enjoining what is right and forbidding what is

wrong. They are the one who attained success" 20 .

The two important points can be highlighted from the above verse; first is calling others to all that is good, and second is enjoining what is right and forbidding what is wrong. Good implies the whole Islamic value system, its beliefs, ideas, ethical principles, and all aspects of life. It can be inferred from the above verse that successful Muslims are those who put the struggle and strife to practice everything which is good in the eyes of God and to refrain everything which is unlawful according to shariah. In the other verse, Allah mentions,

"You are the best community that has been raised up for mankind. You enjoin right conduct and forbid wrong"21.

In this sense, Allah has labeled Muslims as the best ummah who enjoins what is good and forbid what is wrong. Thus, the

\footnotetext{
${ }^{20}$ Qur'an: 5:44.

${ }^{21}$ Qur'an 3: 10.
}

personality of the best ummah is not only having personal virtues but also calling and leading others to the right path of virtue. This has been indeed the practice of the prophets and their successors. After achieving their own perfection, they helped others to achieve the same. The Prophet (p.b.u.h) said,

"Nothing is heavier on the scale than having the good character".

"I was sent to uphold and sanctify the noble characteristics".

"Among the greatest number of people who enter paradise are of the pious and the virtues".

There is no doubt that Islam really stresses on the aspects of having noble characteristics. Moreover, ethics can be considered as the basic pillar for a healthy and firm nation. A society or nation which is devoid of ethical values would always be having problems. Therefore, all scholars and philosophers agreed on the importance of ethics in every individual and society, and considered ethics as the foundation of every society. According to most scholars, the first step in promoting an ideal human society is to advocate refined morality. Indeed, each prophet brought the same message to urge people to uphold a good morality.

In addition, ethics must be counter part of other sciences, such as, law, politics, science, economics, and others for such sciences become soulless or insignificant if detached from ethics. As such, basic ethical principles like justice, freedom, equality, and rights should be exist and applied in all disciplines. Otherwise, they would have been so many problems occurred. So, ethics should exist in each and every field of discipline. For example, there must be certain ethical manners that need to be observed in economics or business in order to ensure that there will be no practices of corruption, oppression, and any other unethical acts. The relationship between ethics and economics has been expounded clearly by Muslim jurists like Qadi Abu Yusuf(d. 799), and Abu Ubayd (d. 834) in their discussion about the concept of justice in economics [8]. In modern term business ethics can be defined as written and unwritten codes of principles and values that govern decisions and actions within a company. It is also an ethics between employers, employees, businessman and consumers. It applies to all businessman and consumers as well as to all aspects of business conduct. It is also relevant to the conduct of individuals and business organization as a whole. Making money or profits is not wrong in business but it should be conducted in right manner, and should not involve any negative elements, such as, cheating or bribery. Therefore, there is an Islamic code of conduct which is meant to be a frame of reference for financial matters, such as, production, trading, distribution, and consumption. These matters of business are not separated from ethical and moral questions in Islam. There are values that must be observed and respected. Islam forbids us to exploit other people or to use unjust method in acquiring wealth. It also has regulated the way of spending which is not be too niggardly and not to be too extravagant but to be a middle cause between these two extremes. In terms of income distribution, Islam suggests it should be done on the basis of justice. Justice in distribution is to make sure that the wealth should not be monopolized by the rich only but should be circulated fairly among the members of the society. That is why we have rules 
and laws of zakah, inheritance, sadaqah, waqf, and baitul mal. In addition, there are some basic socio-economic ethics in the Qur'anic verses and hadith of the Prophet (p.b.u.h), such as, condemn of the use of false weights and measures and other fraud dealings ${ }^{22}$, the prohibition of riba and usury ${ }^{23}$, the prohibition of gambling ${ }^{24}$, the prohibition of bribery ${ }^{25}$, consuming others' property unlawfully ${ }^{26}$, and trading during congregational prayer on Friday ${ }^{27}$.

In the field of politics, ethics is also important in order to ensure that there will be no practice of cronyism, money politics especially during the election, and hegemony of power. Some politicians trying to gain reputation by invalid means, such as, creating false accusation towards other candidates and this would lead to other implications like tension, unstable, unhealthy relationship, disunity, and so on. If politicians neglect to abide by the rules and regulations of morals, the condition eventually turns out to be chaotic and miserable. In reality, politicians can be considered as rulers in which they have big responsibilities to be carried out to ensure the welfare of the people under them. If they are all observing the Islamic ethics, they would be no cases of corruption and negligence of the inferior people. Political ethics, thus, refers to a code of conducts which regulates and guides the behavior of the ruler and the ruled as well as between the government and citizens. Allah mentioned,

"Indeed, God commands you to render back trusts to whom they belong, and when you judge between people, that you judge with justice., ${ }^{, 2}$.

Therefore, justice is one of the most important ethical principles in politics. The Prophet (p.b.u.h) regarded the just ruler as to be one of the seven categories of people who are promised to be given a privilege on the Day of Judgment. He said,

"On the Day of Judgment, the most beloved and closest to God from amongst all people will be a ruler who was just, and the most hated to God and the most severely punished person will be a ruler who was unjust".

Justice here means equal treatment for all people with no distinction and discrimination. It also includes judicial justice in which judgment or decisions should be made on the basis of justice with no distinction between relatives and non-relatives, status of rich or poor people, or personal benefits. A ruler is also prohibited to favor his relatives or to assign them positions which they do not deserve. The Prophet (p.b.u.h) viewed this as a symptom of destruction of a nation. A man once asked the Prophet (p.b.u.h) about the Day of Judgment and he answered, "When trusts are betrayed, wait for the Hour". The man asked, "How are they betrayed?". The Prophet (p.b.u.h) replied; "If positions are given to those who are not worthy of them, wait for the Hour".

Other than that, Islamic ethics should be incorporated in many other fields too such as in science and technology.

\footnotetext{
${ }^{22}$ Qur'an 83:1-3, 6: 152, 55:8-9.

${ }^{23}$ Qur'an 30: 39, 2:278-279.

${ }^{24}$ Qur'an 5:90, 2: 219.

${ }^{25}$ Qur'an 2: 188.

${ }^{26}$ Qur'an 4: 29

${ }^{27}$ Qur'an 62:9-11.

${ }^{28}$ Qur'an 4:58.
}

Nowadays, the advancement of technology makes abundant of new inventions that somehow contradict to the human nature. For instance, the issue of cloning is one of the perennially arguable issues among people. The practice of cloning, though there might be some benefits, still there are many harmful consequences too. Therefore, Islamic ethics rejects cloning as it opposes to human nature; at the same time Islamic ethics cares to prevent harms due to this practice. Islamic ethics is also applied to medicine. It refers to codes of conduct which regulates and guides the behavior of doctors in dealing with each other and the patients. Ethics and medics are related to each other as a doctor should observe his or her own ethics in dealing with patients or in the case of surgery. In the $9^{\text {th }}$ century, the physician Ishaq bin Ali Rahawi wrote the first treatise on Adab al-Tabib (medical ethics). In this treatise, Rahawi labels physicians as guardians of souls and bodies. He also highlights all the deeds and acts that must be observed by a Muslim physician[9]. Therefore, Muslim physician practiced in accordance with the guidance of God. Unlike the secular medicine, Muslim practitioners did not perform abortions or other unethical treatment. Besides Rahawi, al-Razi also observed the relationship between ethics and medicine by taking into consideration the patients' problems and attitudes.

Among the most remarkable works on ethics was done by Ibn Miskawayh. He authored quite systematic treatment of ethics like tahzib al-akhlaq, al-fauz al-asghar, and kitab al-saadah. According to Ibn Miskawayh, the task of ethics is not only to justify and analyze basic concepts but also to discuss the methods of attaining a virtuous life. The whole of Ibn Miskawayh's ethics can be divided into three parts; how to cultivate virtue, how to preserve virtue or maintain of the health of the soul, and how to get rid the soul of vice[10]. The analysis of Miskawayh's idea on the cultivation of virtue discovers that virtue is not a matter of instruction only. For him, the emphasis should be on training and constant practice. Virtue is the result of the regular subordination of the irrational to the rational soul. It means that one keep on doing good deeds if he is at the stage of rationality. As Muslims, to be rational does not mean justifying things based on the intellectual faculty of mind only, but it also involves observing every single aspect of moral conducts whether it is line with the shariah law or not.

For Miskawayh, attainment of ethics in man's life is a lifelong process. He introduced four cardinal virtues; courage, temperance, wisdom, and justice ${ }^{29}$. All of these are identification traits that make up a real Muslim. The description of courage is the ability to express anger, display vigorous and energetic pursuits, ventures in danger and strives for domination, promotion and varieties of honor. Essentially, courage works in the moderate and harmonious state of mind, and it can be eventually manifested to perform the functions and to obey what is prescribed right or wrong for the soul. Therefore, courage is necessary to accomplish the goals of life but it must be manipulated in proper ways. Proper ways connote the implementation of ethics because courageous people are good outwardly. However, if they

\footnotetext{
${ }^{29}$ Abdul Haq Ansari, The Ethical Philosophy of Miskawayh, Aligarh: n. p, 1964, p. 97.
} 
used their courage to subjugate and oppress people it is not regarded as a virtue from Islamic point of view. The other virtue, according to Miskawayh, is temperance. It infers to the person who gratifies his desire in the right measure, in the right way, at the right time, and in the right situation ${ }^{30}$. Miskawayh emphasizes that temperance presupposes the presence of desire and the possibility of their gratification. Temperance is somehow a mean between greed and annihilation of desire. So, virtue is a kind of balancing the soul; not too much and not too little in doing things. Meanwhile, the third virtue, according to Miskawayh, is wisdom which consists of understanding both divine and human knowledge. This noble characteristic enables man to apply what ought to be done and what ought to be avoided. In addition, the other cardinal virtue introduced by Miskawayh is justice. Accor ding to him, this virtue is the most important among all as he claims that courage, temperance, and wisdom are virtues of particular faculties of soul, but justice is the virtue of the entire soul ${ }^{31}$. He claims that justice is a combination of all the three virtues; courage, temperance, and wisdom. He describes that justice is exercised most in social dealings particularly pertaining to the exchange of benefits. Justice too has been said as giving what is due, to whom it is due, and in the way it is due. Indeed, justice is to be applied to own self, to other fellow men in society, and to God. Basically, this moral characteristic is more or less about performing the duties to which it requires ${ }^{32}$. It also educates Muslims not to be bias and not to choose based on own preferences. Rather, it is about exercise fairness to appropriate people and situations

Besides Ibn Miskawayh, al-Ghazali also gives much emphasis on Islamic ethics in which he focused on the importance of fulfilling duties as a human being. According to him, performing duties has two divisions; duties which are directed to God, and duties which are directed towards one's fellow men. It is applied to devotional acts according to shariah and also fulfilling all the rights as an individual. Al-Ghazali mentions that a man has to lead a family life and a life in a community. This requires the implementation of ethics because ethics guides Muslims to keep them onto the right path, and without ethics people would not bother their duties.

\section{CONCLUSION}

In order to ensure the happiness and goodness of life, man needs to refer to the code of ethics to monitor his relationship with God, with his family, with other fellow men in society, with other creatures of the universe, and even with his innermost self. For example, ethics provide some manners in performing ritual obligations, such as, performing five daily prayers within stipulated time and also the manners in reciting the Qur'an in which ablution is necessary and the like. It shows the beauty of Islam that everything should be done in proper ways. Therefore, man cannot ignore the code

\footnotetext{
${ }^{30}$ Ibid, p. 102.

${ }^{31}$ Ibid, p. 107.

${ }^{32}$ Abul Quasem, The Ethics of al Ghazali: A Composite Ethics in Islam, pp. 208-209.
}

of ethics because negligence of it would lead to the deviation and going astray from the straight path of Islam. In terms of the relationship between man and his fellow men, it is clearly mentioned in the Qur'an that Muslims are brothers; thus, one should possess ethical characteristics, such as, helpful, kind hearted, generous, and polite to one another. Similarly, Muslims should not be telling lies to others, spread false news, backbiting, slandering, and other unethical deeds. If every individual abide by the prescribed codes of ethics, people can live peacefully and there would be no cases of crime such as, murder, rape, theft, incest, and prostitution and so on. Therefore, Islamic ethics is vividly vital because it is a basic pillar for a healthy society. It aims at establishing life's order and giving it regulation, dignity and serenity as desired by the teachings of Islam.

\section{REFERENCE}

[1] N. O. Mohd, Christian and Muslim Ethics, Kuala Lumpur: Dewan Bahasa dan Pustaka, 2003, pp. 3.

[2] A. Q. Muhammad, The Ethics of al-Ghazali: A Composite Ethics in Islam, Selangor: National University of Malaysia, 1983, pp. 22.

[3] R. G. Hovanniasian, Ethics in Islam, California: Undena Publications, 1983, pp.11.

[4] M. D. Sheila, Muslim Ethics and Modernity, Canada: Wilfred Laurice University Press, 1984, pp. 5.

[5] M. Fakhry, Ethical Theories in Islam, Netherlands: E. J Brill, 1991, pp. 11

[6] H. A. Abdul, "Islamic ethics: Concept and prospect," The American Journal of Islamic Social Science, Herndon, USA: The International Institute of Islamic Thought (IIIT) \& The Association of Muslim Social Scientists (AMSS),1989, vol. 6, no. 1, pp. 86.

[7] A. S. Abu Ishaq, al-Muwafaqat fi Usul al-Shariaah, edited by Abdullah al-Darraz, Cairo: Dar al Kutub al Ilmiyya, 2005, vol. 1, pp.195.

[8] M. Fakhry, Ethics in Islamic Philosophy and Ethical Theories in Islam, Netherlands: E. J Brill, 1991, pp.11.

[9] A. K. M. Ibrahim. (1986). Morals and Manners in Islam, United Kingdom: The Islamic Foundation. See also Islamic Science: The Scholar and Ethics. [Online]. Available: http:// www.muslimheritage.com.

[10] H. A. Abdul, The Ethical Philosophy of Miskawaih, Aligarh: Aligarh Muslim University Press, 1964, pp. 117

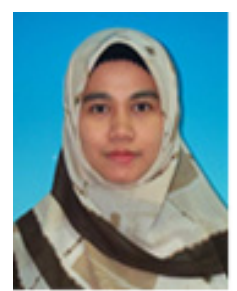

Adibah Binti Abdul Rahim was born at Terengganu, in 1971. She obtained her Ph.D in Islamic revealed knowledge and heritage from International Islamic University Malaysia (IIUM) I 2004. She started her career as an Assistant Lecturer, and was appointed as a Lecturer after completing her Master Degree.

She is currently working as an assistant professor in Kulliyyah of Islamic revealed knowledge and human sciences, IIUM. In 2008, she has been appointed as a Visiting Academic at Monash University, Victoria, Australia during her accomplishment of sabbatical leave. Dr Adibah was appointed as a Project Leader for building taxonomy on Usul al-din, Philosophy, and Comparative Religion for IIUM library. She was also appointed as Principal of Residential College in IIUM. Her academic area of interest is Contemporary Islamic Thought, and she has presented papers at local and international meetings on this area.

Dr Adibah wrote various articles and among them are; Muhammad Farid Wajdi's Discourse on Integration of Religion and Science, in Islamic Revealed Knowledge and Dimensions of Islamic Thought (Kuala Lumpur, IIUM Press 2010), The Impact of Secularism on Muslims Beliefs and Practices, Journal of Islam in Asia, vol. 7, no. 2 (2010), Major Trends of Muslim Responses to the Challenges of Modernity, Journal of Islam in Asia, special Issue, no. 1, March 2011, Muhammad Iqbal's Concept of Selfhood and its Relation to the Society in Islamic Thought and its Contemporary Relevance: A Discourse of Selected Issues( Kuala Lumpur, IIUM Press, 2011) 